\title{
Survey of the Influence of Students With Special Needs for the Achievement of Learning Volunteer Student Volunteers Lambung Mangkurat Banjarmasin
}

\author{
Imam Yuwono ${ }^{1 *}$ \\ ${ }^{1}$ Special education, Faculty of Teacher Training and Educational Sciences, Lambung Mangkurat University \\ *Corresponding author.Email: imam.plb@ulm.ac.id
}

\begin{abstract}
This study aims to determine whether the mentoring process for students with special needs at Lambung Mangkurat University has an effect on student achievement or volunteer learning outcomes in the learning process in class. This study involved 50 volunteers, who accompanied students with special needs, from various types of obstacles. Data collected through interviews, questionnaires and documentation. Data analysis using correlational techniques. The results showed that, volunteer companion students with visual, hearing, physical and behavioral barriers did not affect their learning achievement. While volunteers who accompany students with mental disabilities affect their achievement or learning outcomes.
\end{abstract}

Keywords: Assistance of students with special needs, volunteers, volunteer learning achievements

\section{INTRODUCTION}

Education is essentially a right for everyone. According to Maftuhatin [1] Education is an experience of learning a person throughout life that is undertaken consciously to improve the ability, knowledge, understanding and or skills of a particular. In this case it means that education cannot be put aside from human life, because man needs the name of knowledge, understanding and skills to be able to support his life.

Education in his true nature does not necessarily look at whether the person is rich, handsome, old or young. Because that education is a necessity for everyone without exception. Special children with special needs, those who have barriers also have the right and need to study. This is in line with Rahayu [2], which reveals that all children are entitled to education including children with disabilities.

Lately, inclusive education is indeed an idea of change or revolution in the educational world. Praptiningrum [3] suggests that inclusive education is an Sistem Special Education service that requires all children with special needs to be served at the nearest school in the ordinary class with their peers. In this regard, Yuwono [4] suggests that inclusive education is an education involving special needs (disability) students to study together with their colleagues in public schools, which will cause them to be part of the school community, to create a conducive learning atmosphere. This means that any child in both the general and the child with special needs must be served or schooled at the nearest existing school and include it in the same class in the sense that there is no special class that distinguishes between one child and the other, commonly referred to as discrimination.

Most specialized in Indonesia's own inclusive education has begun to be applied in several schools, both in elementary and secondary schools. And lately also began the implementation of an inclusive education in several universities in Indonesia. Because an inclusive education is an education system that does not discriminate any person who wants to be educated. This is in line with Schmidt and Venet [5] which suggests that inclusive education is an educational program that accommodates all students in the same class according to their age and development. But in fact, according to Hamidi [6], today, the disability has a variety of discrimination actions, especially with the requirements of "healthy physical and spiritual" which becomes the general requirement to enter the level of education that will be pursued and in search of jobs. Surely it is one of the forms of Discrimination against those with disabilities who have certain obstacles. This is actually set in the Republic of Indonesia LAW on No. 20:2003 Article 5 paragraph 2 on Indonesian education system regulation. Because all these things are already set in the law, of course in the process of inclusive education in Indonesia must change and continue to adapt to the achievement of a good and true inclusive education in order to support a competitive generation in the world. And if the inclusive education is going well then the gaps and discrimination that exist in the world of Indonesian education will certainly fade and gradually will create a society that has a high sense of tolerance.

In general, the education system of inclusion is more often seen in schools such as kindergarten (TK) at the first education of children, then elementary school (SD) on the education of both children, then junior high school (SMP) first middle level for children, and there is senior high school (SMA) which is the upper middle level. As for the college level, it is still rare that an inclusive education system is found at college or university levels. This may 
be due to facilities that have not been adequate there and lack of knowledge of inclusive education. Only a few universities have started to implement an inclusive education system, one of which is the University of the Lambung Mangkurat Banjarmasin. Actually, in the implementation of an inclusive class for children with special needs whether it is in the school or in the college could have the same pattern or also can be different, the similarity can be seen on the placement of students with disabilities with regular students in general and which distinguishes it is a high-class demanding inclusive classes that are more complex than the class of inclusion in the school [7]. This means that inclusive education in the college is more complex and not as easy as inclusive education in the school because in the college facilities needed to support the learning of course more and demanded a big responsibility.

According to Tarsidi [8] schools or educational institutions that implement an inclusive education ideology must be able to see and respond to different needs of their students, accommodate and facilitate a variety of learning styles and learning speeds and ensure to provide quality learning for all students. And many more things to be prepared by the Government, especially schools and universities that run an inclusive education system, in order to create an inclusive education system that is good and true. Examples such as preparing facilities suitable for people with disabilities and preparing techniques, methods and media learning that must be suitable for the needs of the disability to be easily accessed by them. This is because the disabled have different obstacles and have different needs that must certainly be in accordance with their abilities. It is therefore very important for educational institutions to be able to accommodate all of them.

To create an inclusive education system in the University of Lambung Mangkurat itself continues to make improvements to become an accessible campus. For that in the university itself there is already a Unit of service (ULD), which contains all elements that can support the passage of an inclusive education system in the University of Lambung Mangkurat. According to The Disability service Unit is tasked to provide services to students with disabilities according to the performance contracts, one of which is to provide a companion and tutor to the students with disabilities ranging from entrance tests to the graduation process [9].

One of the facilities that must be considered and has been applied in the University of Lambung Mangkurat is a human resource or volunteer that will assist or accompany the disability in the university learning process. For that role a companion or volunteer is very large to support an inclusive education at the university. They are certainly required to be able to provide good service for the disabled in the learning process. People with disabilities are able to obtain and receive the material they convey while learning according to their abilities. The service can be in the form of mentoring classes or outside the classroom, peer tutor, can also be a sign language translator and other accommodation that can help students with special needs in accessing college lectures.
According to research conducted by Faiza [10] learning with peer tutors (volunteer) can provide an important influence on behavior, skill, and the ability of children with special needs in socialization in this college is also supported by Adi [11] which reveals that conventional lecture strategy causes most of the students with special needs difficulties in following the lecture. Therefore, Volunteer is indispensable to help students with special needs to be able to perform the learning in the classroom optimally. In the study of Shofa, Riyono, and Giyarsih [12] the Disabled Service Centre or disability service Unit cannot be separated from the accompanying role or volunteer in carrying out its duties to accompany the students with special needs in the campus where the service Unit is located.

The results of the study conducted by Rohaeti [13] showed that the interest of a person to volunteer or volunteer is still very low. This shows that to become volunteer does require a big responsibility. Responsibility for oneself and responsibility to others, and great self-sincerity to help others.

In addition, volunteer or peer tutor also certainly has his own duties and responsibilities as a student he must do besides accompany the students with special needs. They certainly have their own duties and obligations and have them complete as well. And usually volunteers who have a strong commitment and intention to help sincerely who will usually endure being a volunteer. Sometimes there are some volunteer who have difficulty in achieving good learning outcomes because they have to share their mind and physical to accompany students with special needs. Therefore, this research is done to know how the achievement of learning volunteer student beside volunteer is also doing mentoring students with special needs.

\section{RESEARCH METHODS}

The research approach used is using quantitative approaches using correlational methods. This research carried out in the Lambung Mangkurat University. Researchers prefer the campus at Banjarmasin compared to the campus at Banjarbaru, because the center of the disability service unit or volunteer students with the students with special needs (MBK) is located at Banjarmasin campus.

The research centers on two variables namely MBK mentoring and the achievement of volunteer learning. This study involved 50 volunteers who are there at the Lambung Mangkurat University - Banjarmasin, and they are all active students. They will be divided into 5 Mentoring Groups, based on students accompanied by the first this is Group of students with Vision Disabilities, the second group accompanies mental barriers, third group accompanying hearing barriers, the fourth group accompanying the physical barriers of motor and group Fifth accompanying students with behavioral barriers.

The data collection techniques that researchers will use are interviews and polls. This research uses an interview instrument that contains questions related to the mentoring Process and the impact of the mentoring process to the 
outcomes of Learning volunteer, then the study will ask all volunteer related to the mentoring and their learning achievements while studying at the University of Lambung Mangkurat.

Then after all data has been obtained from interviews, poll, and documentation is obtained then researchers will analyse The data using the correlation test Product of the moment as below to know whether the process of mentoring students with special needs will be influential or not to the achievement of learning volunteer at the University of lambung Mangkurat.
The following formulas test correlation product moment:

$$
r_{x y}=\frac{N \sum X Y-\left(\sum X\right)\left(\sum Y\right)}{\sqrt{\left[N \sum X^{2}-\left(\sum X\right)^{2}\right]\left[N \sum Y^{2}-\left(\sum Y\right)^{2}\right]}}
$$

By:

$\mathrm{X}=$ Mentoring Process

$\mathrm{Y}=$ Learning Achievement

$\mathrm{N}=$ Number of Questions

$5 \%$ significant level $=0.632$

Table 1 Grating Instrument

\begin{tabular}{|c|c|c|}
\hline Indicators & Sub indicator & Item Number \\
\hline \multirow{2}{*}{$\begin{array}{c}\text { Process of } \\
\text { Mentoring }\end{array}$} & Mentoring in the classroom & $1,2,3,4,5$ \\
\cline { 2 - 3 } & Mentoring Outside the class & $6,7,8,9.10$ \\
\hline \multirow{4}{*}{$\begin{array}{c}\text { Learning } \\
\text { Achievements }\end{array}$} & Campus achievements & $11,12,13$ \\
\cline { 2 - 3 } & Campus achievements & $14,15,16$ \\
\cline { 2 - 3 } & Academic Achievement & 17.18 \\
\cline { 2 - 3 } & $\begin{array}{c}\text { Non - academic } \\
\text { Achievement }\end{array}$ & 19.20 \\
\hline
\end{tabular}

Table 2 Grid Kisis Interview Instruments

\begin{tabular}{|c|c|c|}
\hline \multirow{2}{*}{ Indicators } & Sub Indicator & $\begin{array}{c}\text { Number of Question } \\
\text { Items }\end{array}$ \\
\hline \multirow{2}{*}{ Process of Mentoring } & The process of mentoring in class & 8 \\
\cline { 2 - 3 } & The process of mentoring outside the class & 4 \\
\hline \multirow{3}{*}{$\begin{array}{c}\text { Learning } \\
\text { Achievements }\end{array}$} & Campus achievements & 3 \\
\cline { 2 - 3 } & Campus achievements & 3 \\
\cline { 2 - 3 } & Academic Achievement & 2 \\
\hline
\end{tabular}

\section{RESULT S AND DISCUSSION}

\subsection{Results}

This research was conducted in 50 people volunteer who perform the process of mentoring the students with special needs and still actively lectured at the University of Lambung Mangkurat. This research wants to find out if the mentoring process affects the outcome or achievement of learning volunteer itself. Data from both variables are obtained from the poll that has been given to the five goup volunteer that contains 10 questions related to the mentoring process and 10 questions related to their learning achievements. Furthermore, the data is analyzed using product moment correlation.

This analysis is done by manual with by calculating the value of $\mathrm{R}$ count that has been obtained from the poll then in comparison with $\mathrm{r}$ table product moment. If the $\mathrm{R}$ Count is greater than the $\mathrm{R}$ table, then both variables have a relationship or influence. Whereas if $r$ count is smaller than the $\mathrm{R}$ table then the two variables have no relationship or do not affect each other.

Table 3 Based on the results of the acquisition of the five volunteers obtained: First Volunteer Group

\begin{tabular}{|c|c|c|c|c|c|}
\hline Questions & The Mentoring process X & Learning outcomes Y & X2 & Y2 & Xy \\
\hline 1 & 5 & 5 & 25 & 25 & 25 \\
\hline 2 & 5 & 5 & 25 & 25 & 25 \\
\hline 3 & 5 & 3 & 25 & 9 & 15 \\
\hline 4 & 3 & 5 & 9 & 25 & 15 \\
\hline 5 & 5 & 5 & 25 & 25 & 25 \\
\hline 6 & 4 & 5 & 16 & 25 & 20 \\
\hline 7 & 4 & 5 & 16 & 25 & 20 \\
\hline 8 & 3 & 5 & 9 & 25 & 15 \\
\hline 9 & 5 & 5 & 25 & 25 & 25 \\
\hline 10 & 3 & 5 & 25 & 25 & 15 \\
\hline Amount & 42 & 48 & 184 & 234 & 200 \\
\hline
\end{tabular}




$$
\begin{aligned}
& r_{x y}=\frac{N \sum X Y-\left(\sum X\right)\left(\sum Y\right)}{\sqrt{\left\{N \sum X^{2}-\left(\sum X\right)^{2}\right\}\left\{N \sum Y^{2}-\left(\sum Y\right)^{2}\right\}}} \\
& =\frac{10.200-(42)(48)}{\sqrt{\left\{10.184-(42)^{2}\right\}\left\{10.234-(48)^{2}\right\}}} \\
& =\frac{2000-2016}{\sqrt{\{1840-1764\}\{2340-2304\}}} \\
& =\frac{-16}{\sqrt{\{76\}\{36\}}}
\end{aligned}
$$

$$
\begin{aligned}
& =\frac{-16}{\sqrt{2736}} \\
& =\frac{-16}{52,306}=-0,0003
\end{aligned}
$$

Because $\mathrm{T}$ Count the result -0.0003 which means smaller than $\mathrm{T}$ table 0.632 with a significance level of $5 \%$, then it can be concluded that in the First Volunteer process of mentoring that done does not affect the achievement or the results of his study.

Table 4 Volunteer Group to two

\begin{tabular}{|c|c|c|c|c|c|}
\hline Questions & The Mentoring process X & Learning outcomes Y & X2 & Y2 & Xy \\
\hline 1 & 4 & 4 & 16 & 16 & 16 \\
\hline 2 & 4 & 4 & 16 & 16 & 16 \\
\hline 3 & 4 & 4 & 16 & 16 & 16 \\
\hline 4 & 4 & 4 & 16 & 16 & 16 \\
\hline 5 & 5 & 4 & 25 & 16 & 20 \\
\hline 6 & 4 & 4 & 16 & 16 & 16 \\
\hline 7 & 4 & 4 & 16 & 16 & 16 \\
\hline 8 & 4 & 4 & 16 & 16 & 16 \\
\hline 9 & 4 & 4 & 16 & 16 & 16 \\
\hline 10 & 4 & 4 & 16 & 16 & 16 \\
\hline Amount & 41 & 40 & 169 & 160 & 164 \\
\hline
\end{tabular}

$=\frac{10.164-(41)(40)}{\sqrt{\left\{10.169-(41)^{2}\right\}\left\{10.160-(40)^{2}\right\}}}$

$=\frac{1640-1640}{\sqrt{\{1690-1681\}\{1600-1600\}}}$

$=\sqrt{9}$

$=3$
Because $\mathrm{T}$ Count the result 3 which means greater than $\mathrm{T}$ table 0.632 with a significance level of $5 \%$, then it can be concluded that in the Volunteer Group the second process of mentoring that does affect His achievement or learning outcomes.

Table 5 Volunteer Group to three

\begin{tabular}{|c|c|c|c|c|c|}
\hline Questions & The Mentoring process X & Learning outcomes Y & X2 & Y2 & XY \\
\hline 1 & 5 & 5 & 25 & 25 & 25 \\
\hline 2 & 5 & 5 & 25 & 25 & 25 \\
\hline 3 & 5 & 5 & 25 & 25 & 25 \\
\hline 4 & 5 & 5 & 25 & 25 & 25 \\
\hline 5 & 5 & 5 & 25 & 25 & 25 \\
\hline 6 & 5 & 5 & 25 & 25 & 25 \\
\hline 7 & 5 & 5 & 25 & 25 & 25 \\
\hline 8 & 4 & 5 & 16 & 25 & 20 \\
\hline 9 & 5 & 5 & 25 & 25 & 25 \\
\hline 10 & 4 & 5 & 16 & 25 & 20 \\
\hline Amount & 48 & 50 & 232 & 250 & 240 \\
\hline
\end{tabular}

$$
\begin{aligned}
& =\frac{10.240-(48)(50)}{\sqrt{\left\{10 \cdot 232-(48)^{2}\right\}\left\{10.250-(50)^{2}\right\}}} \\
& =\frac{2400-2400}{\sqrt{\{2320-2304\}\{2500-2500\}}} \\
& =\frac{0}{\sqrt{16}} \\
& =0
\end{aligned}
$$

Because $\mathrm{T}$ Count the result 0 which means smaller than $\mathrm{T}$ table 0.632 with a significance level of $5 \%$, then it can be concluded that in Volunteer group all three of the mentoring process that does not affect the done achievement or the results of his study. 
Table 6 Volunteer Group four

\begin{tabular}{|c|c|c|c|c|c|}
\hline Questions & The Mentoring process X & Learning outcomes Y & $\mathrm{X} 2$ & $\mathrm{Y} 2$ & $\mathrm{Xy}$ \\
\hline 1 & 4 & 2 & 16 & 4 & 8 \\
\hline 2 & 5 & 4 & 25 & 16 & 20 \\
\hline 3 & 4 & 3 & 16 & 9 & 12 \\
\hline 4 & 3 & 2 & 9 & 4 & 6 \\
\hline 5 & 5 & 4 & 25 & 16 & 20 \\
\hline 6 & 3 & 3 & 9 & 9 & 9 \\
\hline 7 & 3 & 3 & 9 & 9 & 9 \\
\hline 8 & 3 & 3 & 9 & 9 & 9 \\
\hline 9 & 4 & 4 & 16 & 16 & 16 \\
\hline 10 & 4 & 4 & 16 & 16 & 16 \\
\hline Amount & 38 & 32 & 150 & 108 & 125 \\
\hline
\end{tabular}

$$
\begin{aligned}
& =\frac{10.125-(38)(32)}{\sqrt{\left\{10.150-(38)^{2}\right\}\left\{10.108-(32)^{2}\right\}}} \\
& =\frac{1250-1216}{\sqrt{\{1500-1444\}\{1080-1024\}}} \\
& =\frac{34}{\sqrt{\{56\}\{56\}}} \\
& =\frac{34}{\sqrt{3136}}
\end{aligned}
$$

$$
=\frac{34}{56}=0,607
$$

Because $\mathrm{T}$ Count the result 0.607 which means smaller than $\mathrm{T}$ table 0.632 with a significance level of $5 \%$, then it can be concluded that in the Volunteer Group to four process of mentoring that done does not affect the achievement or the results of his study.

Table 7 Volunteer Group Five

\begin{tabular}{|c|c|c|c|c|c|}
\hline Questions & The Mentoring process X & Learning outcomes Y & X2 & Y2 & XY \\
\hline 1 & 5 & 5 & 25 & 25 & 25 \\
\hline 2 & 4 & 4 & 16 & 16 & 16 \\
\hline 3 & 5 & 4 & 25 & 16 & 20 \\
\hline 4 & 4 & 4 & 16 & 16 & 16 \\
\hline 5 & 4 & 4 & 16 & 16 & 16 \\
\hline 6 & 4 & 4 & 16 & 16 & 16 \\
\hline 7 & 4 & 4 & 16 & 16 & 16 \\
\hline 8 & 4 & 5 & 16 & 25 & 20 \\
\hline 9 & 4 & 4 & 16 & 16 & 16 \\
\hline 10 & 4 & 4 & 16 & 16 & 16 \\
\hline Amount & 42 & 42 & 178 & 178 & 177 \\
\hline
\end{tabular}

$$
\begin{aligned}
& =\frac{10 \cdot 177-(42)(42)}{\sqrt{\left\{10 \cdot 178-(42)^{2}\right\}\left\{10 \cdot 178-(42)^{2}\right\}}} \\
& =\frac{1770-1764}{\sqrt{\{1780-1764\}\{1780-1764\}}} \\
& =\frac{6}{\sqrt{\{16\}\{16\}}} \\
& =\frac{6}{\sqrt{256}} \\
& =\frac{6}{16}=0,375
\end{aligned}
$$

Because $\mathrm{T}$ Count the result 0.375 which means smaller than $\mathrm{T}$ table 0.632 with the level of signification $5 \%$, then it can be concluded that in volunteer group the fifth process of mentoring done does not affect the achievement or outcome of the study.
So the result shows that volunteer group 1, 3, 4 and 5 Feel the process of mentoring they do not affect their learning achievement in the campus. In contrast, volunteer group Two feel that the process of mentoring that he has done affects the achievement of his learning.

\subsection{Discussion}

\subsubsection{Student assistance with special needs}

Mentoring is a process or activity aimed at providing ease or a facility provided by a companion to a client in handling all needs and solving problems and encouraging the growth of initiatives in the decision-making process, so that the client will be expected to gain or realize ongoing independence (Clients referred to here are certainly students with special needs) [14]. Based on the understanding of the mentoring that has been mentioned, the mentoring is very important. Of course, there will be a lot of problems found when students with special needs 
follow the learning process in the classroom. This is one of the background of volunteer facilities to the students with special needs in the study bench.

Mentoring has many benefits and positive outcomes in helping to solve problems. Based on the research conducted by Graha [15], the mentoring activity was made as a change agent which was also involved in problem solving. While the research conducted by Kusumaningrum, Arifin, and Gunawan [16], mentoring also gives a significant influence of success to the client. In addition, research conducted by Alia and Irwansyah [17] produces that mentoring brings a positive influence on growth and development.

In addition, based on research conducted by Kisworo, Ilyas, and Kriswanto [18], companion in a college coursework shows the results that Faculty Skills in developing the learning process have been creative. In This study a little discussed about the schedule of mentoring lectures that have also been discussed by Luber, Cholissodin, and Dewi [19] that after being counted based on genetic algorithm. According to the calculation, the results of the mentoring schedule can be done for 5 days. This research was also conducted to follow up the research conducted by Jannah and Sihkabuden [20] which gave the results of the give research in the implementation of mentoring already in accordance with the barriers, characteristics, and needs of students with special needs but students with special needs feel the dependency and eventually slightly charge volunteer.

\subsubsection{Volunteer Learning Results}

Sure, there are many things that can affect the learning outcomes of a student in college. Both internal and external factors. In this research will focus on one of the external factors that affect the student learning outcomes in college, which is the activity that the student has booked. The activities referred to here are the mentoring activities of students with special needs.

Based on this research, it is not too visible the negative influence of this special needs student activities to the results of the volunteer learning. Some mention that this activity can be said to bring a positive influence to their learning process. When they have to divide their time to meet their individual lecture needs they also have an obligation to accompany them and help students with special needs within the same time frame. It certainly makes them discipline. This is in line with the research conducted by Saputro and Pardiman [21] stating that the nature of discipline has a positive influence in learning. The same is also mentioned in the study conducted by Nurfitriyani [22].

In addition, with the activities of this special needs student Assistance, volunteer get a direct experience in handling children with disabilities. Based on the research conducted by Rachmawati [23] the study carried out with a direct down to the field was much more effective than just being stuck to discussions and lectures. Likewise, the research conducted by Nugroho and Hanik [24] who said that the learning done by directly down to the field makes student learning results to increase.

In addition, according to research conducted by Suardana [25] problem-based learning can improve Learning quality and student learning outcomes. As volunteers do help solve the problems of the students with special needs that they accompany. According to research conducted by Saleh [26], students active in the campus environment are postive and significant to their academic achievements.

\section{$\underline{\text { 3.2.3 MBK Mentoring against Volunteer }}$}

\section{learning outcomes}

The results showed that volunteers who accompany students with impaired vision, hearing, physical motoric and resistance behavioral barriers have no effect on their learning outcomes. However but, volunteers who accompany students with mental barriers will have an effect on their learning accomplishments. Students with Mental barriers require more extra assistance, but thus accompanying students with special needs will have a positive influence on both sides. This is in line with the results of this research conducted by Shofa, Riyono, and Giyarsih [12] who said that the programme of the supporting students with disabilities has a positive influence. Surely, the positive influence here is the positive influence felt by students with special needs and volunteers. Research conducted by Faridhavin, Witjaksono, and Harsoyo [27] also said that mentoring activities can affect the perception and knowledge of both parties positively. A study ever conducted by Andayani and Afandi [28] also stated that the relationship between the companion and students with special needs other than in the field of education also makes the support system for both sides.

Because there are some volunteers who are also in the same semester with special needs students who are accompanied. This could be said as a peer tutor. Such research is done by Arjanggi and Suprihatin [29] stating that peer tutoring is becoming a hope to increase the potential of both parties. Setiadi [30] also stated that peer tutors can maximize the learning process. Maximum here certainly for both sides is not only one of course. In fact, the research conducted by Kusuma [31] produces that by this method student learning results can be increased from 67.90 to 81.10 .

\section{CONCLUSION}

\subsection{Case Ofimpulsants}

Based on the results of the analysis conducted by the researcher can be concluded that the process of mentoring conducted by volunteer companation student companion with the barriers of Vision, hearing, physical motor physical and behavior is not too influential about the achievement of learning or their learning outcomes. While volunteer companation student escorts with influential mental barriers. Proven after researchers give a poll to 50 people volunteer which is divided into five groups, only volunteer group two who feel that the process of mentoring influence on his learning achievement, while 
the other 4 group volunteer have a different opinion that the process of mentoring they do not affect the achievement of the learning they can.

\subsection{Advice}

Results Findings above, of course the interest of being a volunteer is still very minimal in a student. But in fact we can see that being a volunteer does not give a big influence on the achievement or the results of the students ' learning, for that we should be students and active role in developing the development of inclusive education in the University of Lambung Mangkurat with an active role as volunteer.

\section{REFERENCES}

[1] L. Maftuhatin, "Evaluasi Pembelajaran Anak Berkebutuhan Khusus (ABK) di Kelas Inklusif di SD Plus Darul 'Ulum Jombang," J. Stud. Islam Oktober, vol. 5, no. 2, pp. 201-228, 2014.

[2] S. M. Rahayu, "Fulfilling children's special needs of early childhood through inclusive education," J. Child. Educ., vol. 2, no. 2, pp. 355-363, 2013.

[3] N. Praptiningrum, "The phenomenon of inclusive education for children with disabilities," J. Spec. Educ., vol. 7, no. 2, pp. 32-39, 2010.

[4] I. Yuwono, "Influence of mentoring and counseling Program on the Visual learning process of middle school students," Int. Spec. Educ., pp. 877-887, 2017.

[5] Schmidt, S \& Venet, M. Principals Facing Inclusive Schooling or Integration. Canadian Journal of Education, vol. 35(1), pp. 217-238, 2012.

[6] J. Hamidi, "Legal protection against disability in fulfilling the right to obtain education and employment," Ius Quia Iustum Law Fac. Law, vol. 23, no. 4, pp. 625-671, 2016.

R. D. Pratiwi., Rusdi., and R. Komala. The effects of personality and intention to act toward responsible environmental behavior. Jurnal Pendidikan Biologi Indonesia, vol.5(1), pp. 169-176, 2019.

[8] D. Tarsidi, "Disability and inclusive education at higher education level," Disabil. Incl. Educ., vol. 11, no. 2, pp. 145-152, 2012.

[9] N. N. Aulia., U. S. Ummah., and A. Samawi. The urgency of the disability service unit in inclusive state universities. Jurnal Ortopedagogia, vol. 5(2), pp. 68-73, 2019.

[10] T. Z. D. Faiza, "Peer mentoring strategy in inclusion student management," 2020.

[11] P. N. Adi, "The influence of the implementation of Peer Teaching learning strategy in the course of occupational therapy on learning outcomes of students with special needs in the extraordinary Education Department of IKIP PGRI Jember," J. Incl. Educ., vol. 2, no. 2, pp. 117-123, 2019.

A. M. A. Shofa., B. Riyono., and S. R. Giyarsih. The role of youths in assisting students with disabilities and its implications for youth personal resilience (study at the Disability Service Center (PLD) UIN Sunan Kalijaga Yogyakarta). Jurnal Ketahanan Nasional, vol. 22(2), pp. 199-216, 2016.

[13] E. Rohaeti, Empowering Students with disabilities in Islamic colleges. Yogyakarta: UIN Sunan Kalijaga, 2009.

[14] Directorate of Social Assistance. Guidance for companions at safe houses and trauma centers. Jakarta: Departemen Sosial RI. 2007.

[15] A. N. Graha, "Development of development community through social assistance in the concept of empowerment in the field of economics," J. Econ. Mod., vol. 5, no. 2, 2009.

[16] D. E. Kusumaningrum., I. Arifin., and I. Gunawan. "Teaching tool development assistance based curriculum 2013," Abdimas Pedagogi. Sci. J. Community Serv., vol. 1, no. $1,2017$.

[17] T. A. \& Irwansyah, "Parental assistance in early childhood in the use of digital technology [Parent Mentoring of Young Children in the Use of Digital Technology]," Polyglot Sci. J., vol. 14, no. 1, pp. 65-78, 2018.

[18] B. Kisworo., Ilyas., and H. D. Kriswanto. "Participatory learning model through mentoring techniques of discussion of student groups in the form of character polite discussion," J. Nonform. Educ., vol. 2, no. 1, 2016.

[19] M. M. H. Luber., I. Cholissodin., and C. Dewi. "Optimization of Damping students with disabilities using genetic algorithm (case study of PSLD Brawijaya University)," J. Inf. Technol. Dev. Comput. Sci., 2017.

[20] M. Jannah. \& S. Sihkabuden, "Implementation of the students disability model with Disability Study Center (PSLD) of Universitas Brawijaya Malang," Orthop. J., vol. 3, no. 1, pp. 45-50, 2017.

S. T. Saputro and P. Pardiman. Pengaruh disiplin belajar dan lingkungan teman sebaya terhadap prestasi belajar mahasiswa Program Studi Pendidikan Akuntansi Angkatan 2009 Fakultas Ekonomi Universitas Negeri Yogyakarta. Jurnal Pendidikan Akuntansi Indonesia, vol. 10(1), pp. 78-97, 2012.

[22] M. Nurfitriyani, "Influence of student creativity and discipline on learning outcomes calculus," Form. Acad. J. Sci. Educ., vol. 4, no. 3, 2015.

[23] D. O. Rachmawati, "Application of Self- 
Directed learning models to improve learning outcomes and self-reliance learning students," 2010.

[24] A. A. Nugroho and N. R. Hanik. "Outdoor Learning implementation to improve student's cognitive learning outcomes in high plant systematics lecture," Bioeducation J. Biol. Educ., vol. 9, no. 1, pp. 41-44, 2016.

[25] I. N. Suardana, "Implementation of problembased development strategy with module assisted cooperative approach to improve the quality of process and student learning outcomes in the lecture," J. Educ. Teach. state IKIP Singaraja, vol. 4, pp. 751-764, 2010.

[26] M. Saleh, "Effect of motivation, family factors, campus environment and active organization of academic achievement," J. Phenom., vol. 4, no. 2, pp. 109-141, 2014.

[27] U. Faridhavin., R. Witjaksono., and Harsoyo. "The perception of program adviser to special effort on food production of paddy, corn and soybean in Yogyakarta Special District," Agro Econ., vol. 27, no. 2, pp. 197-214, 2016.

[28] A. Andayani and M. Afandi, "Empowerment and mentoring of communities with disabilities in accessing universities," Appl. Appl. J. Relig. Sci., vol. 153-166, 2019.

[29] R. Arjanggi and T. Suprihatin, "The learning method of peer tutor enhances learning outcomes based on self regulation," Hubs-Asia, vol. 10, no. 1, 2011.

[30] S. Setiadi. "Peningkatan keterampilan Kitabah Arabiyah mahasiswa melalui metode tutor sebaya". Jurnal Al Bayan, vol. 9(1), pp. 31-39, 2017.

Https://doi.org/10.24042/albayan.v9i1.1094

[31] Kusuma, "Learning effectiveness of peer Tutor assisted by a module to improve student mathematics communication," Horiz. J. Educ., vol. 11, no. 1, pp. 1-8, 2017. 